Abstracta Iranicanica

Revue bibliographique pour le domaine irano-aryen

Volume 40-41 | 2019

Comptes rendus des publications de 2017-2018

\title{
Gunvor Lindström. "The Portrait of a Hellenistic Ruler in the National Museum of Iran"
}

\section{Vito Messina}

\section{(2) OpenEdition \\ 1 Journals}

\section{Electronic version}

URL: http://journals.openedition.org/abstractairanica/48092

DOI: 10.4000/abstractairanica.48092

ISBN: 1961-960X

ISSN: 1961-960X

Publisher:

CNRS (UMR 7528 Mondes iraniens et indiens), Éditions de l'IFRI

\section{Electronic reference}

Vito Messina, "Gunvor Lindström. "The Portrait of a Hellenistic Ruler in the National Museum of Iran"' Abstracta Iranica [Online], Volume 40-41 | 2019, document 14, Online since 15 July 2019, connection on 23 April 2021. URL: http://journals.openedition.org/abstractairanica/48092 ; DOI: https://doi.org/ 10.4000/abstractairanica.48092

This text was automatically generated on 23 April 2021.

Tous droits réservés 


\title{
Gunvor Lindström. “The Portrait of a Hellenistic Ruler in the National Museum of Iran"
}

\author{
Vito Messina
}

\section{REFERENCES}

Gunvor Lindström. "The Portrait of a Hellenistic Ruler in the National Museum of Iran" in Jens M. Daehner, Kenneth Lapatin, Ambra Spinelli (eds.). Artistry in bronze. The Greeks and their legacy. XIX International Congress on Ancient Bronzes. Los Angeles: The J. Paul Getty Museum and Getty Conservation Institute, 2017, p.183-189

1 The bronzes accidentally found at Shami are very well-known to archaeologists. Among other findings, the remains of a portrait of a Hellenistic ruler now in the National Museum of Iran stands out as one of the rare examples of Hellenistic sculpture in Iran. It shows what remains of the face of a beardless sovereign with short hairs larger than life-size. It can be likely dated to the $3^{\text {rd }}-2^{\text {nd }}$ cent. BCE, and its importance rests on the fact that it was dedicated in what is seen as one of the most important sanctuaries of Parthian Iran, and that there is very little evidence of Hellenistic bronzes in Seleucid Asia. This article presents the preliminary results of a project aiming at reconstructing the original facial features of this ruler, likely of the Seleucid dynasty. Although this aim has not been achieved, due to the portrait's intense deformation, the investigations at the National Museum of Iran have already yielded extraordinary results, even the ruler represented still remain unidentified. 


\section{AUTHORS}

\section{VITO MESSINA}

Università di Torino 